This is a preprint of an article submitted for consideration in the JOURNAL OF INTERNATIONAL PEACEKEEPING, Volume 13, Numbers 3-4, September 2009 , pp. 356-382 [copyright Taylor \&

Francis]; available online at:

http://www.ingentaconnect.com/content/mnp/joup/2009/00000013/F0020003/art00005.

\title{
Re-Focusing on Protecting Civilians' Basic Safety and Why We Need to Know Why People Kill On the Latest Reports of the Secretary-General on the Protection of Civilians in Armed Conflict
}

\author{
Evelyne Schmid* \\ evelyne.schmid@graduateinstitute.ch
}

\begin{abstract}
The concept of protection of civilians in armed conflict and the respective roles of peace operations and other actors have not been conclusively defined. This article considers the Secretary-General's latest reports on protection, in particular the two most recent ones (29 May 2009 and 28 October 2007). The author argues that the understanding of effective protection strategies should be informed by a diagnosis of the warring parties' motivations to use deliberate violence against civilians. Analyzing why humanitarian law, human rights law and refugee law are disregarded in many conflicts can help to improve protection strategies. An analysis of the warring parties' motivations may also caution against the belief that there is a system out there that can always protect people in ongoing conflict if only humanitarian actors would improve their modus operandi. Consequently, this article suggests that the notion of protection should remain in close touch with the idea of immediate basic safety. The author recommends that the Secretary-General should insist in future statements and reports that a sound approach to protection requires a diagnosis of why fighting parties chose to attack and threaten civilians. If the diagnosis shows that the armed parties have incentives to disregard basic legal norms and morals; the SC needs to demonstrate real political will to give the concept of protection the meaning it has in conventional language or in the alternative, honestly avoid using it.
\end{abstract}

\section{Keywords}

protection of civilians in armed conflict; United Nations; Secretary-General; Security Council; peace operations; international law; humanitarian law; non-compliance

\section{Introduction}

* Evelyne Schmid is a PhD student in International Law at the Graduate Institute of International and Development Studies, Geneva. The author would like to thank Prof. Ian Johnstone of the Fletcher School of Law and Diplomacy, Dr. Hugo Slim, Director of Corporates for Crisis and former Chief Scholar at the Centre for Humanitarian Dialogue in Geneva, Andreas Weibel and two anonymous reviewers for their valuable comments and suggestions. 
2009 marks the sixtieth anniversary of the Geneva Conventions and the tenth anniversary of the Security Council's (SC) first resolution on the protection of civilians in armed conflict. Ten years after landmark resolution 1265, "protection" is a term that has not been conclusively defined, yet intuitively appeals to a host of actors employing a diversity of approaches. This essay deals with the meaning of the concept of the protection of civilians in armed conflict. It looks at the way the Secretary-General (SG) has dealt with the idea of protection in his reports and the strategies he has recommended to enhance it. While appropriate protection measures need to be tailored to the circumstances of each particular situation, this article focuses on the exchange of ideas between the SG and the SC. The article examines in particular the two most recent SG reports on the protection of civilians in armed conflict: the 2007 report and the most recent report, dated 29 May, released on 17 June and discussed by the Council on 26 June 2009. ${ }^{1}$ The main argument is that the SG's latest suggestions to the SC are insufficiently linked to a diagnosis of the motivations of fighting parties to resort to often atrocious violence against civilians. I will recommend that based on such a diagnosis, the SC should only use the term protection if means to assure a minimum degree of physical safety are part of the approach. From this it appears that it would be more honest to renounce to the notion of protection if the political will and the resources are clearly insufficient to address civilians' most immediate protection needs.

The paper starts with the assertion that the SG's conceptual understanding of protection and the resultant choice of strategies could benefit from taking into account the reasons why warring parties chose to target civilians. The SG's 2007 and 2009 reports on the protection of civilians in armed conflict only marginally address the underlying question why warring parties frequently resort to gruesome violence against non-combatants. This conceptual blind spot gives rise to the misleading belief that there is always a system out there that can protect people in ongoing conflict if only the involved actors add up efforts to implement the wide-range of suggested activities. The choice of the protection strategy employed by international actors often seems not to be primarily based on rigorous diagnosis of the causes of the threats to the civilian population, but rather on the search for compromise in intergovernmental processes or organizations' traditions. Depending on the case, the resulting strategy may work effectively while it may be woefully inadequate in cases where sound diagnosis would show that forcibly displacing people or killing civilians in large numbers is an illegal and unacceptable, though rationally chosen method of warfare. This argument will be illustrated by a textual analysis of the 2007 and 2009 reports of the SG on the protection of civilians in armed conflict.

Given the ambiguity around the concept of protection, I have chosen to restrain the focus to an analysis of the most recent reports of the SG to the SC. An attempt to study the full range of actors and their discordant views on protection would inevitably fill this article with a frittered analysis even if it is certainly true that innovations are often initiated in the field before they are articulated in high-level documents. The disadvantage of extrapolating from a few UN documents is partly compensated by the

${ }^{1}$ For the latest report of the Secretary-General, see S/2009/277. For the 2007 report, see S/2007/643. 
fact that the higher level of analysis is closer to the locus where peace operations - the UN's focal protection actors - are mandated in the first place. The SG has an important role in framing the roles of outside actors intervening in ongoing conflicts and it is at the level of the most powerful member states where the material means for the widest range of options are situated. This is the main reason to study the underpinnings of the debate on protection of civilians at the level of interaction between the SG and the primary organ of the UN responsible for the maintenance of international peace and security. Certainly, in light of the particular way that the reports of the SG are developed, it is clear that decoding a few UN documents might not reveal the ultimate truth. Nevertheless, reading them with a view to the broader contextual developments in peace operations allows discussing to what extent the reports clarify how the concept of protection should be understood, in what way the reports analyze protection challenges and what strategies the SG recommends to address them.

Understanding why the law is disregarded in many armed conflicts is an important step for improving intervention strategies. Analyses on the decision-making, objectives and economic and social functioning of warring parties should systematically be linked to deliberations on protection strategies. The research of political scientists can usefully shed light on how to understand the goals and commitments of violent actors in conflicts. This article pleads for linking such research with the suggestions made by the SG. Obviously, the SG's reports address protection on a general level and can not be expected to take into account all specific circumstances of all ongoing conflicts. However, the SG's recommendations on protection could be enhanced by conceiving the violence suffered by civilians not simply as an empirical fact, but as an unacceptable tough to a large extent rationally allegeable method of warfare. The article recommends that the SG should insist in future reports that a sound approach to protection requires a diagnosis of why fighting parties chose to attack and to threaten civilians. Further, I suggest that the Council should only describe an activity as protection if the aspect of effectively responding to threats against the immediate safety of civilians is part of the Council's reaction.

The article proceeds as follows: Section I starts with a brief exposé of the development of the concept of protection. Even if the subsequent argument of this article focuses on the SG's reports to the SC, it is useful to outline the institutional development of the concept. I will argue that the lack of a common definition of the protection of civilians is not surprising given the ambiguous normative environment. At the same time, the lack of a common definition seriously complicates debates on protection. Section II reasons that the use of political violence against the civilian population should in the vast majority of cases - not be portrayed as "blind slaughter" but can often be conceived in rational terms. This view is supported by a considerable body of literature which will be briefly mentioned. Section III links this political science argument to the suggestions contained in the SG latest reports on the issue and criticizes that these reports do not clearly state that a diagnosis of the reasons for non-compliance should be the starting point of choosing any protection strategy. Section 
IV cautions that the term protection should not be used too broadly and tentatively endeavors to suggest how and when the Council should employ the notion of protection to describe its activities. The article concludes that the SG should make it much clearer that there are reasons for noncompliance with laws and morals and that these reasons should be taken into account when discussing the potential of the various protection strategies. Secondly, he should resist confining the discussion to general statements on an ever widening number of issues. Instead, it is hoped that he succeeds in recommitting member states to a concept of protection which has basic physical safety at its core.

\section{Brief Overview of the Concept of Protection: An (Unsurprising) Lack of Common Vocabulary}

This section contains a brief outline on the development of the concept of protection. The growing interest in the topic stems from the awareness that in most armed conflicts, civilian populations are directly targeted rather than chiefly being indirect victims. ${ }^{2}$ Undoubtedly, the concept of protection is grounded in the norms contained in the Geneva Conventions and the protocols thereto. The idea that even in war a certain group of people should be put outside the fight is both fragile and ancient. It is the idea that the choice of means and methods of warfare is not unlimited. While the concept of protection is rooted in international humanitarian law, these legal norms have provided a range of actors with a policy rationale for a wide spectrum of activities.

However, there is no consensus what activities and practices fall within the protection umbrella. The lack of a common definition of protection is not surprising if one employs a social constructivist reading of the changing normative environment. The disasters of Somalia, Rwanda and Bosnia have significantly - but not conclusively - altered the way international actors conceive their role faced with unprotected civilians. In February 1999, the President of the SC for the first time requested that the SG submits recommendations how to improve the protection of civilians in armed conflict. $^{3}$ Since then, the SG has delivered seven thematic reports on protection. ${ }^{4}$ In 1999, a report on Srebrenica and an inquiry into Rwanda recognized that there can be situations in which repeating the legal provisions protecting civilians may be grossly insufficient. The same year, the SC passed

\footnotetext{
${ }^{2}$ UN Office for the Coordination of Humanitarian Affairs (OCHA), Protection of Civilians in Armed Conflict Online Information, http://ochaonline.un.org/HumanitarianIssues/ProtectionofCiviliansinArmedConflict/tabid/1114/Default.aspx, 21 January 2009.

3 S/PRST/1999/6.

${ }^{4}$ S/1999/957, S/2002/331, S/2002/1300, S/2004/431, S/2005/740 and S/2007/643 and S/2009/277. See also: A/RES/55/2 (2002) and Kofi Annan, Protecting Civilians in Armed Conflict: Towards a Climate of Compliance (New York: OCHA, 1999).
} 
landmark resolution 1265 which laid down a set of principles for responding to threats against civilian populations. ${ }^{5}$

Between 1996 and 2000, the International Committee of the Red Cross (ICRC) convened a series of workshops and adopted a broad definition of protection. At these workshops, some fifty organizations discussed the protection of civilians in armed conflict with a view to define the term. The involved agencies defined protection as encompassing

all activities, aimed at obtaining full respect for the rights of the individual in accordance with the letter and the spirit of the relevant bodies of law (i.e. human rights, humanitarian and refugee law). ${ }^{6}$

The workshop participants reached consensus that protection activities included three spheres of action:

- Responsive action aims at stopping, preventing or mitigating patterns of abuse;

- Remedial action aims at restoring people's dignity and ensuring adequate living conditions and assisting people living with the effects of abuse;

- Environment-building action fosters an environment conducive to respect for the rights of individuals in accordance with the relevant bodies of law. ${ }^{7}$

The ICRC workshops undoubtedly resulted in a broad understanding of the term protection. Such a holistic view directs our attention to the manifold interrelationships between different challenges faced by civilians in armed conflict. At the same time, one may ask whether such a broad definition does not simply encompass most activities humanitarian actors normally pursue.

Shortly after the publication of the ICRC workshop proceedings, the UN Office for the Coordination of Humanitarian Affairs (OCHA) prepared an Aide-Memoire to guide the UN Security Council in its deliberations related to civilians in armed conflict. ${ }^{8}$ The Aide-Memoire was conceived as a checklist for Council members when considering the establishment, change or close of a peace operation. In 2003 and recently in January 2009, updates of the Aide-Memoire were adopted and annexed to presidential statements. ${ }^{9}$ The original Aide-Memoire identified thirteen core objectives for protecting civilians in armed conflict. The document also contained a list of references to previous resolutions and presidential statements pertaining to each of the objectives. The updated version of

\footnotetext{
5 S/RES/1265 (1999).

6 Sylvie, Giossi-Caverzasio, Strengthening Protection in War: A Search for Professional Standards: Summary of Discussions Among Human Rights and Humanitarian Organizations: Workshops at the ICRC, 1996-2000 (Geneva: ICRC, 2001). [Thereafter Giossi-Caverzasio, Strengthening Protection in War.]

7 Ibid., pp. 19-24.

8 S/PRST/2002/6.

9 S/PRST/2003/27; and S/PRST/2009/1.
} 
2003 retained this structure but slightly changed the emphasis of the core protection priorities. ${ }^{10}$ The most recent version of the Aide-Memoire is organized somewhat differently. The 2009 version is significantly less concise and is not presented in the form of a table as were the two previous versions. It contains a section on general protection concerns and two sections on specific concerns, namely of children and women affected by armed conflict. Each section includes numerous sub-headings listing issues for consideration, such as access to vulnerable populations; safe, voluntary and dignified return of refugees and internally displaced persons; small arms and mine action; respect for the safety and security of humanitarian workers; or accountability for persons suspected of international crimes. An addendum to the 2009 Aide-Memoire contains a selection of agreed language used in previous SC resolutions.

All three versions of the Aide-Memoire do not define the term protection in the abstract. They highlight primary objectives for Council action and list the most frequently encountered issues for consideration. The advantage of the approach used in the Aide-Memoires is to systemize the deliberations within the SC and to ensure that important issues are not omitted. At the same time, the list of objectives is almost as broad as the ICRC workshop definition and seems to encompass "all the good things" a peace operation is ideally capable of accomplishing. In October 1999, the SC for the first time mandated a mission to take the necessary action to "afford protection to civilians under immediate threat of physical violence" in the case of the United Nations Mission in Sierra Leone (UNAMSIL) ${ }^{11}$. Four months later, the Council gave its mission in the Congo the ambitious mandate of, inter alia, "taking the necessary action, in the areas of deployment of its troops and as it deems it within its capabilities, to protect civilians under imminent threat of physical violence."12 In practice, the two early versions of the Aide-Memoire have most certainly had some impact on deliberations on the design of peace operations and the term protection has entered the language mandate of peace operations. Nevertheless, the lack of consensus on the conceptual limits of protection has also been manifested in debates in the Council. The Security Council Report, an independent organization affiliated with Columbia University, diagnosed that at times, some members seemed to merge protection of non-combatants with an ever widening range of other issues. Others seemed to be steering the concept into areas such as conflict prevention, the provision of adequate resources to peacekeeping operations or the appropriate use of sanctions. ${ }^{13}$

\footnotetext{
10 The thirteen groups of objectives described in the 2003 Aide-Memoire were the following: Security for displaced persons and host communities; access to vulnerable populations; safety and security of humanitarian personnel; security and the rule of law; disarmament, demobilization, reintegration and rehabilitation; small arms and mine action; women; children; justice and reconciliation; training of peacekeeping forces; countering hate speech, managing information; addressing the impact of natural resources; minimizing the humanitarian impact of sanctions. S/PRST/2003/27.

11 S/RES/1270 (1999), para. 14.

12 S/RES/1291 (2000), para. 8. See also: Katarina Månsson, 'Use of Force and Civilian Protection: Peace Operations in the Congo', International Peacekeeping, vol. 12, no. 4, 2005, pp. 503-505.

13 Cross-Cutting Report No. 2: Protection of Civilians, 14 October 2008, p. 3, http://www.securitycouncilreport.org/site/c.glKWLeMTIsG/b.4664099/k.1776/CrossCutting_Report_No_2brProtection_of _Civiliansbr14_October_2008.htm, 8 January 2009. [Thereafter Cross-Cutting Report: Protection of Civilians.]
} 
As in the case of the mission in the Congo, current protection mandates often contain the clause that the mission is mandated to take "necessary action to afford protection to civilians under imminent threat of physical violence, in the areas of deployment of its infantry battalions and as it deems it within its capabilities [emphasis added]. ${ }^{14}$ Such caveats are not only an indication of the practical challenges of protection against physical threats but they also indicate that that those who trumpet the arrival of a new era of humanitarianism might be deluded. At the same time, the position that mandates of peace operations must reflect humanitarian objectives has undoubtedly strengthened. ${ }^{15}$ In brief, some ambiguities on the use of the term protection can be found in the mandates themselves. In addition, definitional uncertainties with regard to protection may also be due to the fact that the debate on protection has been influenced by the related - but not congruent - discussions on the responsibility to protect (R2P) and on humanitarian intervention. It is crucial to distinguish these concepts. The protection of civilians is grounded in the widely accepted norms of international law, humanitarian law in particular. On the other hand, the idea of humanitarian intervention was strongly resisted since it proposed that it could override the UN Charter and legitimize the use of force to stop a humanitarian crisis. R2P is a third and distinct concept which relates to crimes such as genocide, war crimes and crimes against humanity. As with protection, its contours are also diffuse. The divergent interpretations of the Outcome Document of the 2005 World Summit are a good illustration of both the verbal endorsement of R2P as well as uncertainties whether the incorporation of the responsibility to protect clause indeed indicates a normative change. In one reading - which I share - the Outcome Document merely affirms the rules contained in the UN Charter by insisting on SC authorization to use force. ${ }^{16}$ Others have interpreted the Document as a "revolution in consciousness in international affairs" ${ }^{17}$ While such debates are ongoing, it is crucial to delineate protection from these related debates, especially since observers have claimed that some have attempted to politicize the issue of protection by exploiting the sovereignty controversy so vividly present in the debates on $\mathrm{R} 2 \mathrm{P}$ and on humanitarian intervention. ${ }^{18}$ Even if the international community remains deeply divided on how principles of national sovereignty and humanitarian need should be reconciled, ${ }^{19}$ it is crucial to note that the idea of civilian protection is based on universally accepted norms of international law, in particular the notion that the right of armed parties to choose methods or means of warfare is not unlimited.

\footnotetext{
14 S/RES/1291 (2000), para. 8.

15 All peacekeeping operations "share certain common aims - to alleviate suffering, and create conditions and build institutions for self-sustaining peace”. See: DPKO Mission Statement, http://www.un.org/Depts/dpko/dpko/info/page3.htm, 6 October, 2008.

16 A/RES/60/1 (2005), para. 139.

17 Todd Lindberg, 'Protect the people; United Nations takes bold Stance', The Washington Times, 27 September 2005.

18 Cross-Cutting Report: Protection of Civilians, p. 4.

19 Richard Gowan, Ian Johnstone, 'New Callenges for Peacekeeping: Protection, Peacebuilding and the War on Terror', Coping with Crisis Working Paper Series, March 2007, p. 4.
} 
This box attempts to offer an overview of the various forms of protection.

It is important to note that the idea of protection is often either discussed with regard to non-military means only or on the other hand melted with a discussion on humanitarian intervention and the use of full scale military force. This article is however interested not primarily in the means of protection, but in the concept itself and how protection approaches could be enhanced. The main argument is precisely that the choice of the means of protection should flow from an analysis of the warring parties' motivations to target civilians and the specific circumstances of the conflict. Schematically, we can distinguish the following angles of analyzing the forms of protection:

Protection by the national state, armed groups and civilians themselves: The primary responsibility for the protection of civilians rests with domestic authorities. ${ }^{20}$ At the same time, armed groups have a direct responsibility to spare civilian populations in armed conflict. Moreover, it is of utmost importance to note that protection is not simply a conversation conducted above the heads of those affected by conflict, but that the civilians themselves are key players with their own specific and often sophisticate protection strategies.

A useful distinction can be made between the idea of physical protection and protection of the legal status of civilians in times of war. Moreover, a distinction can be made between immediate and longer term approaches. Many analysts believe that the protection of civilians is the result of functioning states. Therefore, they assume that support to improve the conditions for state institutions to succeed is the best way to protect a population in the long run.

Humanitarian agencies have made constant efforts to develop what protection means in practice and a considerable number of manuals guide their fieldwork. ${ }^{21}$

Unsurprisingly, ambiguities in the normative framework are reflected in the practice of the SC and may also influence the SG when drafting his reports on protection. The fact that power tends to adopt

\footnotetext{
20 A/RES/46/182 (1991), para. 4.

21 UNICEF and UN Inter-Agency Standing Committee, Growing the Sheltering Tree: Protecting Rights Through Humanitarian Action (New York: UNICEF, 2003). OCHA, Manual on Field Practice in Internal Displacement (Washington DC: Brookings, 1999). Liam Mahony, Proactive Presence: Field Strategies for Civilian Protection (Geneva: Center for Humanitarian Dialogue, 2006). Deborah Mancini-Roth, André Picot, Humanitarian Negotiation: A Handbook for Securing Access, Assistance and Protection (Geneva: Center for Humanitarian Dialogue, 2004). Global Protection Cluster Working-Group, Handbook for the Protection of Internally Displaced Persons (Geneva: UNHCHR, 2007). UNHCHR, Handbook for the Protection of Women and Girls (Geneva: UNHCHR, 2008). Nina Birkeland, Ellen Vermeulen, Tor Vågli, Camp Management Toolkit (Oslo: Norwegian Refugee Council, 2004).
} 
humanitarian discourse underlines the strategic significance of the language of civilian protection but does not equate that states and international bodies are suddenly converted to humanitarianism. ${ }^{22}$ The next section explores what civilians need to be protected from. It finds that they rarely need to be protected from blind slaughter but more often from rationally employed violence. Section II therefore asserts that understanding why law and morals are disregarded in many armed conflicts is an important step for improving protection strategies.

\section{Protection from Blind Slaughter or Rationally Employed Violence?}

This section argues that the use of violence against the civilian population is often a deliberately chosen method of the warring parties. It refutes the argument that the wars of the post Cold-War era are characterized by irrationality. This assessment will be the basis for Section III which analyses the latest reports of the SG and reveals a lack of diagnosis of the reasons for atrociously violent behavior. Section II is grounded in the assumption that misinterpreting dynamics in armed conflicts has negative ramifications on the design and success of the chosen protection strategies.

Authors such as Enzensberger have argued that post Cold-War conflicts were characterized by the use of irrational violence committed by "autistic perpetrators". ${ }^{23}$ Writing on the Balkans, Kaplan described the reactionary anger of each country at the others and the "people condemned to a history of bloodshed and hatred". ${ }^{24}$ Empirical studies have however challenged the view that today's armed conflicts could not be understood by rationality. ${ }^{25}$ While overestimating the distinctiveness of post Cold-War conflicts, Kaldor recognized that widespread atrocities in current conflicts were not just side effects, but often a deliberate strategy for political control. ${ }^{26}$

A cursory survey of political science literature on this issue supports this view. As the "greed or grievance" controversy structured the debate on intrastate wars, at least the greed-based explanations explained that violence was rationally chosen. ${ }^{27}$ Fearon's famous article on 'Rationalist Explanations of War ${ }^{28}$ was transposed into the analysis of intrastate wars. ${ }^{29}$ Other authors advanced instrumentalist accounts to explain how elites appeal to group allegiance. ${ }^{30}$ Common to these rationalist explanations is the expectation that where other ways of gaining at least the same benefits

\footnotetext{
${ }^{22}$ Simon Chesterman, Civilians in War (Boulder: Lynne Rienner Publishers, 2001), p. 185. [Thereafter Chesterman, Civilians in War.]

${ }^{23}$ Hans-Magnus Enzensberger, Civil Wars: From LA to Bosnia (New York: New Press, 1994), p. 20.

24 Robert Kaplan, Balkan Ghosts: A Journey Through History (New York: St. Martin's Press, 1993), Synopsis.

25 Erik Melander, Magnus Öberg, Jonathan Hall, The "New Wars" Debate Revisited: An empirical Evaluation of the Atrociousness of "New Wars" (Uppsala: Uppsala University, 2006).

26 Mary Kaldor, New and Old Wars: Organized Violence in a Global Era (Stanford: Stanford University Press, 1999).

27 Mats Berdal, David Malone, 'Greed and Grievance: Economic Agendas in Civil Wars', Peace Research Abstracts, vol. 39, no. 2, 2002, pp.155-306.

28 James Fearon, 'Rationalist Explanations for War'. International Organization, vol. 49, no. 3, 1995, pp. $379-414$.

29 James Fearon, David Laitin, 'Ethnicity, Insurgency, and Civil War', American Political Science Review, vol. 97, no. 1, 2003, pp. 75-90.

30 John Mueller, 'The Banality of "Ethnic War"', International Security, vol. 25, no. 1, January 2000, pp.42-70.
} 
exist, rational actors would not chose violent means - or at least limit them. ${ }^{31}$ A common objection to such rationalist reasoning is that contemporary forms of violence must be irrational since they inflict such huge costs in human terms. However, labeling something as "rational" does by no means equate that it is acceptable. A few examples help to illustrate how atrocities are often carefully planned rather than gratuitous and random. It was said that the Revolutionary United Front in Sierra Leone (RUF) lacked ideology and political aims. ${ }^{32}$ But because the RUF did employ shocking methods does not mean that the underlying motives of the rebel army's leadership can not be grasped in rational terms. Richards provides an analysis of the strategically motivated rebel violence. He argues that a set of simple calculations lay behind the savage:

The insurgent movement spreads by capturing young people. Short of food in the pre-harvest period, some captives, irrespective of the risks, sought to defy the movement and return to their villages where the early harvest was about to commence. How could the rebels prevent such defections? By stopping the harvest. When the news of rebel amputations spread in central Sierra Leone (...) few women were prepared to venture out in the fields. The harvest ceased.... 33

Violence perpetrated by government forces has similarly been explained by reference to rational motives. Valentino et al. have argued that in order to cut the popular support to a rebel movement, governments often chose to attack civilians in order to induce the population to stop providing a subsistence basis for the rebels. ${ }^{34}$ At a terrible human cost, this strategy matches the definition of rationality. It is important to note that such practices are not particular to "dark Africa". For instance, sexual violence was part of a deliberate process at the end of WWII. A study concluded that mass rape served effectively as an unofficial maneuver to frighten and intimidate the population of East Berlin into complying with the wishes and demands of its Soviet occupiers. ${ }^{35}$

While the behavior illustrated by such examples is not only wholly unacceptable but clearly contrary to the law, the pattern of violence nevertheless followed considerations of utility maximization. Hugo Slim, former scholar at the Centre for Humanitarian Dialogue, recently published a book analyzing what he terms "R2K" - the reasons to kill. ${ }^{36}$ Rather than relying on finger pointing by repeating the relevant legal provisions, he asks how involved actors can make belligerents fight in accordance with the principles of limited war. The author suggests basing the choice of protection strategies on the analysis of the fighting party's thinking and their relationship with the civilian

\footnotetext{
31 See for instance: Ted Gurr, Barbara Harff, Ethnic Conflict in World Politics (Boulder: Westview Press, 1994).

${ }^{32}$ Ibrahim Abdullah and Patrick Muana, 'The Revolutionary United Front: A Revolt of the Lumpenproletariat' in Christopher Clapham (ed.), African Guerillas (Oxford: James Currey, 1998), pp. 172-193.

33 Stathis Kalyvas, '"New" and "Old" Civil Wars: A Valid Distinction?', World Politics, vol. 54, no.1, October 2001, p. 116.

34 Benjamin Valentino, Paul Huth, Dylan Balch-Lindsay, “Draining the Sea”: Mass Killing and Guerrilla Warfare', International Organization, vol. 58, no. 2, May 2004, pp. 375-407.

35 James Messerschmidt, 'The Forgotten Victims of WWII: Masculinities and Rape in Berlin', Violence Against Women, vol. 12 , no. 7 , July 2006 , p. 706.
} 
population. Avenues of influence may be based on conviction, coercion, incentives and rights-based approaches. Can fighters be made believe that civilians should not be killed, even if their civilian identity might often be ambiguous? Is coercion (by military means but also by legal structures, etc.) necessary? Incentives could include gaining the respect of the concerned population or the international community. The growing awareness of the civilians themselves about their rights in armed conflict might be an increasingly important source of pressure and influence. In brief, to determine the most promising strategy, Slim advises us to look at the "reasons to kill" and the anticivilian ideologies which underpin the targeting of civilians. A concise guide for fieldworkers summarizes the analysis to think through the perspective of the perpetrators of civilian suffering. ${ }^{37}$

Similarly, to anticipate the grim dynamics mentioned above, Marie-Joëlle Zahar suggests analyzing the relations between the civilian population and warring parties. Zahar has hypothesized that that the more heavily a militia depends on the population; the more likely the movement will be to limit harm to civilians. Inclusive and broad long-term objectives are more likely to generate sensitivity to issues of civilian protection than narrow interest. ${ }^{38}$ Her analysis could usefully inspire prescriptive analysis with regard to the protection of civilians. For instance, a rebel movement that conceives itself as the "government in waiting" will strike for legitimacy and can thus be expected to respond to strategies that enable it to demonstrate its capacity to uphold humanitarian law. As an example of strategies relying on this reasoning, a Geneva-based NGO induces rebel movements to sign a commitment for adherence to a ban of anti-personnel mines. In turn - while its compliance is monitored - the movement receives assistance in mine action. ${ }^{39}$ Zahar would argue that such an innovative approach works best with a group that depends on legitimacy among the civilian population and that strives for inclusive and broader long-term goals. On the other hand, she would caution that armed parties who do not materially depend on the civilian population or whose war aim is to eradicate or forcibly displace civilians are unlikely to change their behavior through such an intervention. Taking this logic one step further, if the diagnosis reveals that a warring party falls within Zahar's latter category, a peace operation of the ideal world would not be expected to "protect" the civilian population by activities such as reporting their abuses to the international community. In addition, a recent publication of the Berghof Research Center summarizes case-studies on six insurgency movements. Presenting comparative findings from Aceh, Colombia, Nepal, Northern Ireland, South Africa, and Sri Lanka, the report analyzes how choices between violent and non-violent strategies are

\footnotetext{
${ }^{36}$ Hugo Slim, Killing Civilians: Method, Madness and Morality in War (New York: Columbia University Press, 2008).

37 Hugo Slim, Deborah Mancini-Griffoli, Interpreting Violence: Anti-Civilian Thinking and Practice and How to Argue Against it More Effectively (Geneva: Centre for Humanitarian Dialogue, 2008).

${ }^{38}$ Marie-Joëlle Zahar, 'Protégés, Clients, Cannon Fodder: Civil-Militia Relations in Internal Conflicts' in Chesterman, Civilians in War, pp. 43-65. Another author who should be mentioned is Stephen Stedman, 'Spoiler Problems in Peace Processes', International Security, vol. 22, no. 2, 1997, pp. 5-53.

39 Geneva Call, Engaging Non-State Actors, http://www.genevacall.org/home.htm, 21 January 2009.
} 
made to achieve certain political ends. ${ }^{40}$ Studying the internal and external factors which influenced armed movements' strategic choices may be the key to anticipate civilians' protection needs and possible avenues to address them.

A sound diagnosis on "the reasons to kill" should thus precede the selection of protection strategies. Understanding belligerents in their relation to civilian populations helps to highlight that there are a number of persistent patterns in war, recurrent dynamics that either protect or expose civilians to death and displacement. As highlighted in the SG's report "No Exit Without Strategy", the SC "should reach agreement on clear and achievable mandates for peace operations based on a common understanding of the conflict" [emphasis added]. ${ }^{41}$ In the cases outlined above, certain people decided to kill, maim, rape or starve others and to violate the rules of the law. If we can understand their decision-making, we might also be able to recognize avenues to influence their behavior. That is not actually a very revolutionary idea. Indeed, it is important to acknowledge that many actors in the field have accumulated a wealth of experiences in applying such thinking in their daily work. Nevertheless, the point made in the next section is the idea of taking into account warring parties' incentives and their ideological justifications to target civilians is not sufficiently employed in the reports of the SG to the Council.

\section{The Secretary-General's Latest Reports on the Protection of Civilians in Armed Conflict}

The SG submitted his seventh report on protection on 29 May 2009 and Council members held an open debate on 26 June 2009. ${ }^{42}$ Before the 2007 and 2009 reports are analyzed in more detail, it makes sense to look back at the earlier reports and their recommendations:

\section{An Inventory of Previous Recommendations}

The inventory of the main recommendations contained in previous SG reports can broadly be clustered around the following issues:

- Legal protection: Calls for ratification and implementation of treaties, compliance of peacekeepers, accountability for crimes, the implementation of the Guiding Principles on Internal Displacement, etc.;

\footnotetext{
40 Véronique Dudouet (ed.), From War to Politics: Resistance/Liberation Movements in Transition (Berlin: Berghof Research Center, 2009), in particular pp. 19-25.

41 S/RES/394 (2001), para. 44.

${ }^{42} \mathrm{~S} / 2009 / 277$. For the records of the open debate, see S/PV.6151.
} 
- Physical protection: Conflict prevention and preventive deployment, ${ }^{43}$ investigations and factfinding missions, control of hate speech, information dissemination, separation of combatants and civilians in camps, DDR, coercive action as a mechanism of last resort in the face of massive and ongoing abuses;

- Humanitarian access: Urging all actors to ensure unimpeded access, calls for coordinated access negotiations and contact with non-state actors $;^{44}$

- Special vulnerability of women and children: Require parties to make arrangements for assistance of children and women, etc.;

- Sanctions: Targeted sanctions with minimum adverse effects;

- Monitoring and reporting: Monitor regional organizations' efforts ${ }^{45}$ measure and document the number of civilians killed, tortured or displaced, the number of civilians denied access to assistance, or the number affected by sexual violence. In later reports, reporting is also recommended for cross-boarder problems (human trafficking, illicit arms trade, etc.); ${ }^{46}$

- Rule of law, justice and reconciliation: National justice reform, studying the role of peace agreements.

The 2001 report is the only one which contains an attempt to define protection. It describes protection as "a complex and multi-layered process, involving a diversity of entities and approaches. It depends on the circumstances and stages of a particular conflict". ${ }^{47}$ Apart from this indication, the reports have in common that they describe a number of protection activities rather than providing an abstract definition of the concept. The central tenet of this article is whether recommendations on protection take into account the motivations of warring parties to threaten civilians. Several previous reports do indeed, if only in a cursory fashion, link the diagnosed threats with the calculations of the parties to a conflict. The earliest and the most recent report on protection of civilians are the most notable in this respect. The 1999 report mentions that the deliberate targeting of civilians often serves the purpose of hastening military surrender or of gaining economic control. ${ }^{48}$ The 2004 report acknowledges that forced displacement can be a deliberate strategy of warfare. ${ }^{49}$ The 2004 report also contains an analysis of "rape as a weapon"; preparing language adopted by the Council in its recent resolution $1820 .^{50}$ Notable is also the 2005 report which states that attacks on civilians and their property are

\footnotetext{
43 Preventive deployment and conflict prevention are emphasized in the 1999 report: S/1999/957, para. 44-47.

44 The 2002 report (S/2002/1300, para. 17-30) as well as all three versions of the Aide-Memoire (S/PRST/2002/6 and S/PRST/2003/27 contain detailed suggestions with regard to access negotiations.

${ }^{45}$ In 1999, some level of suspicion towards regional efforts can be found in the SG's report (S/1999/957, para 26, 62-63 and recommendations 25 and 34). Subsequent reports increasingly called to support and enhance regional efforts.

46 The call for enhanced monitoring and reporting is very strong in the 2004 report: S/2004/431, para. 46-47, 51.

47 S/2001/331, para. 6.

$48 \mathrm{~S} / 1999 / 957$, para. 8, 13.

49 S/2004/431, para 4.

50 S/RES/1821 (2008).
} 
often used "to make sure there is no return". 51 The 2005 report suggests that since there have been new challenges to the safety and well-being of civilians, "our tools to address these concerns need to be developed accordingly." ${ }^{, 52}$ Even if some of the previous reports have acknowledged the idea that warring parties may pursue rational aims in targeting civilians, apart from the above mentioned reference in the 2005 report, there has been no statement that such a diagnosis should be the starting point of the design of protection strategies. The 2007 report is almost entirely silent in this respect while the 2009 report shows some improvement. In a first step, the 2007 report is analyzed in detail, followed by an update on how the SG has dealt with the issue in his latest report.

The 2007 report notes four overarching protection challenges: First, humanitarian access; second, sexual violence; third, the need to address the effects of conflict on housing, land and property and fourth, the toll of cluster munitions. As the earlier reports, the 2007 report presents a pessimistic view of the implementation of legal norms and the situation of civilians in armed conflict. As in all previous reports, the SG makes proposals regarding the ratification of treaties, the development of the normative framework and the need to strengthen conflict prevention. With regard to the definitional challenges of protection, the report lacks groundbreaking innovations. Like the previous reports, the 2007 report recommends a number of activities rather than conceptualizing the notion of protection itself. Through the recommended activities and strategies, the 2007 report indirectly offers insight into the understanding of protection.

The main recommendations contained in the report include the following:

- Conduct of Hostilities: A requirement for strict compliance with IHL in all relevant SC resolutions;

- Sexual Violence: Requesting comprehensive information on sexual violence in all reports on UN missions; referring situations of widespread abuse to the International Criminal Court (ICC) and/or considering targeted sanctions;

- Access: Mandating UN missions to contribute to the creation of security conditions for humanitarian assistance;

- Housing, Land and Property: Including language in all relevant resolutions on the right of return; promoting the establishment of domestic mechanisms for addressing such issues;

- Establish a Council Working-Group to facilitate consideration and analysis of protection concerns.

$51 \mathrm{~S} / 2005 / 740$, para 13, 20.

52 Ibid., para. 54. 
First of all, the SG should be appraised for his insistence that progress will be measured by achievements on the ground. ${ }^{53}$ What is in my view less fortunate is that the report to a large extent reads like a shopping-list containing desirable elements of any successful conflict intervention; rather than a precise discussion of the role of the Council and its members. It is certainly hard for member states to disagree on the desirability of the stated changes and no member state would argue that less sexual violence and better humanitarian access are not worthwhile goals. The problem with such an approach is that it does not engage the question why civilians in armed conflict are deliberately targeted. Answering this question should inform strategies and help determining responsibilities to reverse "our collective failure to ensure effective protection for civilians". 54

The paragraphs outlining the issues of concern adhere to the following structure: First, the SG mentions the general problem (e.g. §21, "the erosion of the principles of distinction and proportionality”). In a second step, the SG notes the legal norms prohibiting a certain behavior. Third, a list of examples illustrates the prevalence of the problem. Examples either include the geographic locations where the problem frequently occurs and/or a further assessment of the situations in which it is most likely to take place. Finally, the SG outlines his recommendations. What this structure does not comprise is why acts disregarding the laws of armed conflict are so widespread. A simple way to analyze the report is to look at the language used to describe the violence threatening civilians. As mentioned above, previous reports have contained some limited references to underlying reasons to resort to violence against civilians. The most recent report does not deny that rational calculations may underpin non-compliance with elementary norms and morals, nor does it describe the violence against civilians in terms of barbarity or senseless slaughter. Simply, the SG presents the violence as empirical facts we witness. ${ }^{55}$ The exceptions are a paragraph in which the SG addresses possible reasons for violating basic legal norms when he mentions asymmetry in some armed conflicts and another paragraph on sexual violence. ${ }^{56}$ The SG mentions that militarily weaker parties deliberately attack civilians while militarily superior parties often violate the principles of distinction and proportionality because they face difficulties to identify their enemy. ${ }^{57}$ This comes closest to contextualizing the targeting of civilians as an issue which is not independent of rational considerations. The general impression is however that the analysis of the report starts with a stock-taking of violence as an externally given circumstance and that the report does not contain a prescription to systematically diagnose reasons for non-compliance before assessing the merit of various strategies.

As follows from Section II, considering the underlying reasons of the use of brutal violence could offer some guidance on the comparative advantages of different strategies. The absence of a

\footnotetext{
$53 \mathrm{~S} / 2007 / 643$, para. 3, 10, 20, 48, 66 and 67.

54 Ibid., para. 43.

55 Ibid., para. 21-24.

56 Ibid., para. 45 where the SG writes that "these [acts of sexual violence] are not random acts (...) but a deliberate attempt to dehumanize and destroy entire communities".

57 Ibid., para 7.
} 
statement that this consideration should be made systematically weakens the strength of the SG's recommendations. An example illustrates this. One of the SG's main recommendations with regard to the conduct of hostilities is that the SC should systematically include "a requirement for strict compliance with IHL, as well as human rights law, in all resolutions authorizing UN peacekeeping and other relevant missions". 58 In light of the fact that the previous 65 paragraphs of the report contain numerous accounts of widespread non-compliance with applicable law, it remains doubtful how a requirement for compliance would reliably affect the situation on the ground. If one applies Zahar's reasoning explained above; armed actors striking for international legitimacy may indeed respond to calls in Council' resolutions. Clearly, others will not. To enhance his recommendations, the SG should specify possible measures to be taken in case his suggestions fail to have a tangible effect and he should attempt to include a requirement that Council members analyze the origins of threats to civilians.

It is without doubt much easier to point out the weaknesses of the report's recommendations than to find a way to enhance them, especially given the political factors limiting the SG's marge de manoeuvre. It is clear that the SG faces a strained context when presenting his recommendations. This does not seem to have significantly changed in 2009. On 27 May 2008, an unspectacular presidential statement was issued; taking note of the 2007 report and requesting a next report in May 2009. ${ }^{59}$ The Council held an open debate on January 14, 2009 in which the third version of the Aide-Memoire was adopted. ${ }^{60}$ It identifies protection concerns and maintains a focus on the role of peace operations, but also includes a range of other measures that could be taken by the Council, such as imposing targeted sanctions and the referral of situations to the ICC. While little progress had been made during 2008, it is encouraging that the Council has also finally taken up some of the 2007 recommendations of the SG. On 16 January 2009, the first meeting of a Council Expert Group on Protection was convened by the UK. ${ }^{61}$ The Expert Group provides a significant opportunity to identify the most appropriate means of enhancing protection in the Council's resolutions and actions and it remains to be hoped that its establishment marks the beginning of a re-commitment of the Council.

On 17 June 2009, the SG made public his latest protection report. ${ }^{62}$ As regards the above outlined criticisms, the 2009 report and its annex on access constraints contain remarkable elements of analytically assessing the reasons of non-compliance. The 2009 report is also an improvement insofar as the SG more clearly states what action should be taken, and by whom, in cases of non-compliance. The SG mentions that the need to strengthen protection "lies, in part, in the changing nature of conflict in the last 10 years", the proliferation and fragmentation of non-State armed groups and the

\footnotetext{
58 Ibid., para. 66(a).

59 S/PRST/2008/18.

${ }^{60}$ S/PRST/2009/1. For the official record, see S/PV.6066 and S/PV.6066 (Resumption 1).

61 Security Council Report Chronology, http://www.securitycouncilreport.org/site/c.glKWLeMTIsG/b.4012209/, 3 May 2009.

$62 \mathrm{~S} / 2009 / 277$.
} 
increasingly asymmetric nature of conflict". According to him, [t]his has had a profoundly negative impact on civilians, as armed groups have sought to overcome their military inferiority by using strategies that flagrantly violate international law, including attacks against civilians and the use of civilians to shield military objectives. The risks for civilians are further heightened as militarily superior parties, in fighting an enemy that is often difficult, if not impossible, to identify, respond with methods and means of warfare that may violate the principles of distinction and proportionality." 63 As 2009 marks the tenth anniversary of the consideration by the SC of the protection of civilians in armed conflict as a thematic issue, the SG reviews the past decade of protection debates. ${ }^{64}$ As in 2007 , the SG states that normative developments are of limited value if they do not translate into improvements on the ground. ${ }^{65}$ In a very sober remark, the SG observes: "Significant though they are, for all the reports, resolutions and actions of the last decade, the situation that confronts civilians in current conflicts is depressingly similar to that which prevailed in 1999." ${ }^{66}$ More manifestly than in previous reports, the SG does not hide his dissatisfaction with the way the Council has (or has not) acted upon his previous recommendations. ${ }^{67}$ It is encouraging that the SG uses clear language when diagnosing that "there remains a disconnect between mandates, intentions, expectations, interpretations and real implementation capacity" and "[t]his means that the 'protection of civilians' mandate in peacekeeping missions remains largely undefined as both a military task and as a mission-wide task.",68 Compared to the 2007 report, another positive aspect of the 2009 report is the fact that it contains at least some allusion on how the depressing observations from the field relate to the concrete role of actors and explicit statements on who is required to do what. ${ }^{69}$ In short, the latest SG protection report to some extent contextualizes the targeting of civilians and reminds the various actors of their respective role in protection. While the 2009 report is analytically stronger than its predecessor, the SG's sober statements reveal underlying frustrations with the resulting outcomes of the last decade of protection as a thematic issue.

A few days after the release of the 2009 report, Human Rights Watch urged Council member ambassadors to translate "endless commitments" into effective action, particularly in relation to the situation in the DRC, Sudan, Chad and Sri Lanka. ${ }^{70}$ During the past few years, the Council's thematic

\footnotetext{
$63 \mathrm{~S} / 2009 / 277$, para. 24.

64 Ibid., paras. 6-13.

65 Ibid., para. 14.

66 Ibid., para. 23.

67 Ibid., para. 17, and 30-34. The SG urges the Council to revisit the recommendations of the 2007 report, concerning refugees and displaced persons, housing, land and property issues. He clearly criticizes the parties to the conflict in Sri Lanka and in Gaza as well as in Afghanistan in paras. 30-34.

68 Ibid., paras. 51-52.

69 See for instance Ibid., para. 44 where the SG insists on the role of member States to promote compliance by armed groups. See also paras. 59, 64, 66 and 76 which are all addressed to specific actors (the Council, Member States, non-State parties to the conflict).

${ }^{70}$ Human Rights Watch, 'Security Council Debate on Protection of Civilians in Armed Conflict', http://www.hrw.org/node/84000, 25 June 2009.
} 
involvement on protection seems to have decreased and the focus dissipated. Observers note that members seem increasingly to confine discussions to general statements on a wide number of topics, but without a clear indication of concrete steps forward. ${ }^{71}$ Whether this loss of momentum has been due to dissent around issues of human rights affairs, the US invasion of Iraq, concerns with terrorism or the limited capacity of the global peace operations machinery in general; a re-commitment of the Council is a major political task.

Even after the two first protection reports in 1999 and in 2000, the Council shielded away from a number of recommendations, including the establishment of a Working-Group on volatile situations. The idea that "information is power" may partly account for the SG's absence of a statement to link the concept of protection with a diagnosis of the sources of threats to civilians. The cost of agreeing to strategies that apparently fall short of the diagnosis that sound analysis would provide might significantly increase for the members of the SC. As an example, had the SG pushed Council members to study in detail the protection needs of the Iraqi population, this would have entailed a closer look at the performance of the Multinational-Force and the Iraqi government. ${ }^{72}$ Further, my suggestion to study the functioning and motivations of armed groups encounters the problem that states are generally disinclined to strategies that deal with armed non-state actors if these are perceived to legitimize movements challenging the government. It is also well-known that where robust protection by the UN is most needed, the incentives to provide it are modest. Against that background, the weaknesses of the SG's reports may be a symptom of more general global challenges. Even if unable to suggest a conclusive remedy to deal with these constraints, the next section attempts to develop some preliminary ideas how the SG could conceptualize protection in order to facilitate re-focusing the debate on protection. Mainly, it seems important that the notion of protection - at least if used by the SC - should not be employed too loosely to describe all possible activities addressing the plight of civilians. Rather, the SC should only be invited to use the term if it remains in close touch with the idea of civilians' basic safety.

\section{Re-committing Council Members to a Concept of Protection which Has Immediate Protection Needs at its Center}

While it is easier to say what does not work to protect civilians, the much more daunting challenge is to alleviate the definitional problems of protection and most importantly to find and implement strategies able to confront the underlying rational incentives threatening civilian populations. Given the argument of this article on the importance of understanding each situation's background, an

71 Cross-Cutting Report: Protection of Civilians, p. 8.

${ }^{72}$ Ibid., p. 14. 
abstract definition of protection would not be a panacea. The present section suggests that it is preferable not to apply the term protection too loosely. Rather, the notion of protection should remain in close touch with the meaning it has in everyday language. Protection in conventional language includes at its core the idea of physical integrity. If sound analysis reveals that the available means and political will fall very short of responding to threats to immediate safety; I would consider it more honest if the SC would not employ the term. Therefore, in my view, the SG should avoid offering Council members the option to pick and choose other activities from a broad menu and "sell" them as protection. In situations where direct responsive action would be needed to protect civilians' most basic safety, it is not provided by the SC; calling all other activities protection raises false expectations, defies common sense and conceals the lack of political will.

As mentioned in Section I, an understanding of protection was developed during the ICRC led interagency workshops in the late 1990s. Three levels of intervention conceptualize protection: the most immediate sphere of action concerns responsive action aiming to stop or alleviate the abuses. The second sphere involves remedial action helping people to recover from violations. The third sphere deals with structural action to build an environment conducive to respect for the rights of the individual. ${ }^{73}$ The idea of thinking about protection in three spheres helps to explain my argument why the SG and the SC should narrow the use of the term. Since the responsive sphere is the one to address civilian's most immediate protection needs, I find it problematic if the Council uses the term protection for activities which decisively fall short of ensuring basic safety. My main suggestion is that the SG should not invite Council members to speak of protection when analysis shows that the abuses against the civilian population are part of a deliberate strategy which can not be countered by the available means or the prevalent political will. Another way to express this thought is to say that the term protection should not be used by the Council if almost no resources are available for action in the responsive sphere. There are cases where sound analysis of the motivations of armed parties may reveal that to counter their abusive behavior, a far more robust approach would be required. I would advise the SG and the SC not to describe the activities as protection if the SC confines itself to the second and third spheres of action (remedial action and environment-building). A further evaluation of two aspects of the 2007 report illustrates this argument:

The first aspect concerns paragraph 47 of the 2007 report. It notes that most perpetrators of sexual violence go unpunished and that crimes often remain unreported. The SG therefore requests the "systematic provision of comprehensive information on sexual violence as a specific annex to all reports to the Security-Council". ${ }^{74}$ This is a very valuable recommendation since such information may provide the basis for effective assistance. Also, documentation is crucial for most, if not all,

\footnotetext{
73 Hugo Slim, Andrew Bonwick, Protection: An ALNAP Guide for Humanitarian Agencies (Oxford: Active Learning Network for Accountability and Performance in Humanitarian Action, 2006), p. 42. The model is retained in the excellent and recent ICRC publication on the subject: ICRC, Enhancing Protection for Civilians in Armed Conflict and Other Situations of Violence (Geneva: ICRC, 2008), p. 26.
} 
mechanisms of transitional justice. But assuming that massive sexual violence is part of a strategy and assuming that the SC is not otherwise responding; framing the reliance on reporting as a protection activity seems problematic. It seems legitimate to ask whether victims would consider post factum reporting without a more direct response as a protection strategy. As outlined in Section II, one could imagine that the activities recommended by the SG might be an effective response in situations where naming and shaming has an effect on the behavior of an armed group. On the other hand, they are likely to be inadequate in situations where perpetrators commit sexual violence as a weapon of war and do not depend on legitimacy among the international community or the concerned population. In such situations, reporting and other activities may still be invaluable to remedy harm, but we should not believe that they function as responsive protection action. In my view, the ordinary meaning of the term protection implies that invoking the concept must remain in touch with the idea of physical safety. I would suggest that reporting can indeed be an essential aspect of protection, but that the SG should not lead the Council to believe that it makes sense to call all additional activities in the second and third sphere of action protection if the threats to civilians seem to require more direct responsive action and the Council fails to provide it.

A second aspect of concern with regard to the 2007 report's approach is the following: Still with regard to sexual violence, paragraph 50 asks that "prevention and response activities by humanitarian actors must be strengthened and better coordinated", implicitly assuming that "prevention and response" come from "humanitarian actors". This wording leaves open to interpretation whether the SC or its member are considered humanitarian actors. The phrasing avoids discussing the role that member states and the SC could, should or do play and insofar avoids the debate of the responsibility of the UN's organ charged with the maintenance of international peace and security. The drawback of allowing Council members to describe all sorts of activities as protection independent of considering whether there is a chance to influence the underlying "reasons to kill" is that it hides the fact that a lack of political will is at the basis of employing strategies that in reality do not match the challenge.

In short, what I am suggesting is that the SG provides clarity that protection can only be done if the responsive component is sufficiently assembled and if strategies build on an analysis of the origins of threats to civilians. The situation in the eastern Congo provides an illustration of an approach to protection almost entirely lacking responsive capacities. On 4-5 November, 2008, an estimated 150 people were killed in a town half a mile away from the field base of UN peacekeeping forces in an area considered a priority protection zone. ${ }^{75}$ MONUC is overstretched and essentially relies on the shaky cooperation of the Congolese armed forces to protect the civilian population. With four fighting vehicles, no interpreter for most of the time and a number of aid workers to evacuate, the newly

${ }^{74} \mathrm{~S} / 2007 / 643$, para. 66 . 
arrived Indian peacekeepers could devote few resources to go out and protect civilians under attack. ${ }^{76}$ On 22 December, the SC unanimously extended the mandate of the mission while slightly reinforcing its strength. ${ }^{77}$ The basic problem of a huge gap between expectations and capacities to respond to immediate threats against civilians remains acute. Applying the above mentioned suggestion to this situation would mean that the SC would continue to engage in activities in the second and third spheres of action; but would not employ the notion of protection to describe activities such as reporting, monitoring or providing freedom of movement for UN personnel.

To sum up, the lack of an agreed definition of what falls within the protection umbrella has led to situations where the concept of protection is frequently invoked but where often few capacities are put available for responsive action. It is quite clear that my suggestion to narrow the use of the term is not a conclusive improvement. At least two challenges come to my mind. First, the suggestion suffers from the imprecision of the threshold of how much responsive action is needed to invoke protection. Second, as outlined in Section I, the challenges with the concept of protection relate to the decentralized and ambiguous nature of international crises responses and the SG faces a formidable task in disciplining members' use of a thematic concept.

While not suggesting to exclude the common sense assertion that protecting one life is better than none and doing something short of the ideal might still be worth it, the linkage of serious violations and the maintenance of international peace and security has made it more urgent to bridge the current disjunction between high intentions and weak resolve. As a way forward, sound analysis of the warring parties' behavior should inspire the crafting of protection strategies before the term is invoked ad nauseam. Even if it is sometimes difficult to determine the motivations of the perpetrators and their affiliation; ${ }^{78}$ where a diagnosis shows that the armed parties have rational incentives to disregard IHL, human rights and refugee law; the SC needs to demonstrate real political will to give the concept of protection the meaning it has in conventional language.

\section{Conclusion}

This article has argued that the choice of protection strategies should be grounded in an analysis of why belligerents resort to violence against civilians. While it is encouraging that the report issued in 2009 at least honestly diagnoses the lack of clarity of protection as a task of peace operations, the

\footnotetext{
75 Human Rights Watch, Killings in Kiwanja: The UN's Inability to Protect Civilians (New York: HRW, 11 December 2008), p. 1-2.

76 Ibid., p. 25.

77 S/RES/1856 (2008).

78 John Holmes, 'Statement to the Security Council on Protection of Civilians', 27 May, 2008, http://ochaonline.un.org/OchaLinkClick.aspx?link=ocha\&DocId=1003428, 11 October, 2008. OCHA should be acknowledged for its work in identifying programmes which are seen by parties to a given conflict as more acceptable in order to find possible entry points from which operations can be expanded.
} 
current situations in a number of countries cast doubt on the strategic use of the concept. This article has recommended that SC should not apply the term protection too loosely to all kinds of activities in situations where physical protection is needed, but not provided through the chosen strategies. Applying the notion of protection too loosely helps to hide the fact that often a lack of political will is at the basis of employing strategies that do not match the challenge. That is why the article has maintained that the recommendations of the SG - as exemplified by the discussion of his latest thematic reports - are a rather evading approach to protection as they do not engage with the difficult questions of when and how to combine humanitarian ends with well defined and effective, including sometimes military means.

My suggestion for a narrower use of the term should not be viewed as the attempt to provide a definite answer to the complex problems raised in this article. However, I hope that focusing on the need to amass capabilities for responsive action to stop, prevent or alleviate violations whenever the term protection is invoked contributes to the ICRC's thought that the three spheres of action must complement each other. If there is no actor able to address the responsive sphere, the sum of activities is unlikely to add up to the common-sense understanding of protection. Why this does by far not mean that actors should stop to work on the two other spheres of action, I am suggesting that in such cases, it might be more useful if the SC would use other language to characterize the activities; for instance by describing them as monitoring, humanitarian assistance, security sector reform, or whatever best describes them.

Asking why the warring parties chose to deliberately attack civilians should be the starting point of designing a protection strategy. I hope the previous sections have made clear that if the warring parties are not or can not be motivated to protect civilians themselves, short of robust responses, there is no such a thing as a system of protection that can actually protect people. ${ }^{79}$ There is a limit on what outcomes can be achieved through humanitarian action, notwithstanding their great importance. As Jones and Cater have put it, in cases where belligerents see an important strategic and political gain from directly attacking civilians, the onus shifts to those responsible for collective security. ${ }^{80}$ Hence, whenever the SC employs the term protection, Council members should make sure that the notion remains in close touch with the meaning it has in everyday language.

\footnotetext{
79 James Darcy, 'IRIN Interview with James Darcy on Protection in Armed Conflict', 2007, http://www.irinnews.org/InDepthMain.aspx?InDepthId=31\&ReportId=70567, 10 October, 2008.

80 Jones and Cater, 'From Chaos to Coherence?' in Chesterman, Civilians in War, p. 243.
} 